Int. J. Electrochem. Sci., 16 (2021) Article ID: 210738

International Journal of

ELECTROCHEMICAL

SCIENCE

www.electrochemsci.org

\title{
Chiral Separation by Capillary Electrophoresis based on Hyper- branched Materials
}

\author{
Xiangqing Yang \\ School of Chemical Engineering and Light Industry, Guangdong University of Technology, \\ Guangzhou, 510006, China \\ E-mail: Xiangqing-Yang@protonmail.com, xiangqingyang2021@163.com
}

doi: $10.20964 / 2021.07 .37$

Received: 22 March 2021/ Accepted: 5 May 2021 / Published: 31 May 2021

In order to improve the chiral separation effect of capillary electrophoresis, a method based on hyperbranched materials was proposed. The mechanism of chiral separation in capillary electrophoresis was analyzed by using the capillary as a separation channel and high voltage direct current as the driving force. The experimental procedure was included preparation of the chiral separation by capillary electrophoresis, synthesis and preparation of hyper-branched materials and capillary, preparation of buffer solution and sample solution, and setting up chiral separation conditions of electrophoresis. Thus, combined with the chiral separation mechanism, the chiral separation by capillary electrophoresis was realized. Compared with the traditional separation method, the separation degree of the proposed separation technique was higher which indicates a significant improvement in the separation effect.

Keywords: Hyper-branched materials; Capillary; Electrophoresis; Chiral separation

\section{$\underline{\text { FULL TEXT }}$}

(C) 2021 The Authors. Published by ESG (www.electrochemsci.org). This article is an open access article distributed under the terms and conditions of the Creative Commons Attribution license (http://creativecommons.org/licenses/by/4.0/). 